\title{
Energy balance measurements over a banana orchard in the Semiarid region in the Northeast of Brazil
}

\author{
Carlos Antonio Costa dos Santos ${ }^{(1)}$, Bernardo Barbosa da Silva(2), Tantravahi Venkata Ramana Rao ${ }^{(2)}$ and \\ Christopher Michael Usher Neale ${ }^{(3)}$
}

(1)Instituto Nacional de Pesquisas da Amazônia, Avenida André Araújo, no 2936, Aleixo, CEP 69060-001 Manaus, AM, Brazil.
E-mail: carlostorm@gmail.com (2)Universidade Federal de Campina Grande, Unidade Acadêmica de Ciências Atmosféricas, Avenida Aprígio Veloso,
no 882, Bodocongó, CEP 58109-970 Campina Grande, PB, Brazil. E-mail: bernardo@dca.ufcg.edu.br, ramanarao_tantravahi@yahoo.com.br (3)Utah
State University, Biological and Irrigation Engineering Department, 4105 Old Main Hill, Logan, UT 84322, USA. E-mail: christopher.neale@@usu.edu

Abstract - The objective of this work was to evaluate the reliability of eddy covariance measurements, analyzing the energy balance components, evapotranspiration and energy balance closure in dry and wet growing seasons, in a banana orchard. The experiment was carried out at a farm located within the irrigation district of Quixeré, in the Lower Jaguaribe basin, in Ceará state, Brazil. An eddy covariance system was used to measure the turbulent flux. An automatic weather station was installed in a grass field to obtain the reference evapotranspiration $\left(\mathrm{ET}_{0}\right)$ from the combined FAO-Penman-Monteith method. Wind speed and vapor pressure deficit are the most important variables on the evaporative process in both growing seasons. In the dry season, the heat fluxes have a similar order of magnitude, and during the wet season the latent heat flux is the largest. The eddy covariance system had acceptable reliability in measuring heat flux, with actual evapotranspiration results comparing well with those obtained by using the water balance method. The energy balance closure had good results for the study area, with mean values of 0.93 and 0.86 for the dry and wet growing seasons respectively.

Index terms: Musa, dry season, eddy covariance, latent heat flux, sensible heat flux, wet season.

\section{Medidas do balanço de energia sobre pomar de bananeira na região Semiárida do Nordeste do Brasil}

\begin{abstract}
Resumo - O objetivo deste trabalho foi avaliar a confiabilidade da técnica das correlações turbulentas, analisando as componentes do balanço de energia, a evapotranspiração e o fechamento do balanço de energia nas estações de crescimento seca e úmida, na cultura da banana. O experimento foi realizado em uma fazenda localizada no distrito irrigado de Quixeré, na Bacia do Baixo Jaguaribe, Ceará. Foi utilizado um sistema de correlações turbulentas na obtenção das medidas dos fluxos turbulentos. Uma estação meteorológica automática foi instalada em um gramado para a obtenção da evapotranspiração de referência $\left(\mathrm{ET}_{0}\right)$ pelo método FAO-Penman-Monteith. A velocidade do vento e o deficit de pressão do vapor são as variáveis mais importantes no processo evaporativo em ambas as estações. Na estação seca, os fluxos de calor têm ordens de magnitude similares, enquanto na estação úmida o calor latente é superior. O sistema de correlações turbulentas apresentou confiança aceitável na obtenção dos fluxos de calor, com a evapotranspiração real mostrando valores similares aos obtidos pelo método do balanço hídrico. O fechamento do balanço de energia apresentou bons resultados para a área de estudo, com valores médios de 0,93 e 0,86 para as estações seca e chuvosa, respectivamente.
\end{abstract}

Termos para indexação: Musa, estação chuvosa, correlações turbulentas, calor latente, calor sensível, estação seca.

\section{Introduction}

Agriculture is the largest global water consumer. Irrigated agriculture can be responsible for inefficient water use, either through low application efficiency or inadequate irrigation scheduling. Excessive irrigation results in higher production costs and negative environmentalimpacts(Paço et al., 2006). In the semiarid region of Brazil, water scarcity and, consequently, the methods to save water are increasingly relevant, stressing the need of accurate water requirement estimates. Good irrigation management to improve crop water use efficiency is important for sustainable economic development (Silva et al., 2009).

It is generally accepted that banana needs large quantities of water for high production. However, it

Pesq. agropec. bras., Brasília, v.44, n.11, p.1365-1373, nov. 2009 
is difficult to quantify its water use, and the basis for the high water requirements is not well understood (Lu et al., 2002). Water is probably the most limiting nonbiological factor in banana production. Robinson (1995) noted that the water requirements are met by effective rainfall and irrigation, and the proportion of water for banana production derived from these two sources varies widely throughout the world. Banana have rapid growth, high water consumption, a shallow and widely distributed root system, low resistance to drought and quick physiological response to soil water deficit (Robinson, 1995; Bassoi et al., 2004).

The consumptive water use, or actual evapotranspiration (ETa), can be estimated by micrometeorological methods, soil depletion techniques, or by using weighing lysimeters. Eddy covariance (EC) is a micrometeorological technique that has several distinct advantages, particularly over tall canopies (Baldochi, 2003; Giolia et al., 2004; Simmons et al., 2007; Teixeira et al., 2008). Independent methods of evaluating the reliability of the EC measurements are highly desirable. Despite being among the most advanced in situ measurement methods that directly provide ETa, eddy covariance is widely known to have energy balance closure problems. This closure requires that the sum of the measured latent (LE) and sensible $(\mathrm{H})$ heat fluxes be equivalent to all other energy sinks and sources (Wilson et al., 2002). The imbalance in the directly measured surface energy fluxes has been discussed by a number of authors (Verma et al., 1986; Tanaka et al., 2003). Stannard et al. (1994) reported that the typical value of the closure ratio for agricultural land is of 0.8-0.9. Wilson et al. (2002) suggested that the surface energy fluxes $(\mathrm{LE}+\mathrm{H})$ are frequently, but not always, undermeasured by about $10-30 \%$ regarding estimates of available energy, i.e. the difference between net radiation $\left(R_{n}\right)$ and soil heat flux $(G)$.

Due to the need for information on banana crop water requirements in tropical regions, an important goal of this study was to analyze the actual evapotranspiration during the entire growing season of the crop. Thus, the objectives of our study were to examine the reliability of EC measurements, to study the energy balance components in the dry and wet growing seasons; and to analyze the evapotranspiration and the energy balance closure in a banana orchard in the semiarid region of Brazil.

\section{Materials and Methods}

The experiment was carried out at the Frutacor

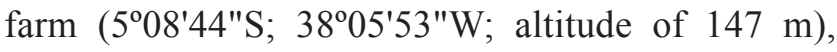
with an approximate area of 250 ha of irrigated banana orchard (Musa paradisiaca L.), between October 2005 and June 2006. This farm is located in the Quixeré irrigation district, of the Lower Jaguaribe basin, in Ceará state, Northeast Brazil. The area has a semiarid BSw'h'-type climate according to the Köppen classification. The mean air temperature is $28.5^{\circ} \mathrm{C}$, with maximum and minimum values of $36^{\circ} \mathrm{C}$ and $22^{\circ} \mathrm{C}$, respectively, and mean relative humidity of $62 \%$. The mean total annual rainfall is $772 \mathrm{~mm}$ and the mean annual evaporation is $3,215 \mathrm{~mm}$.

The plantation was installed in 2000, on a Cambisolo Háplico (Inceptisol) soil type (Sistema Brasileiro de Classificação de Solo, 1999), with $4 \mathrm{~m}$ spacing between rows and $2.4 \mathrm{~m}$ between plants. During the experiment, the average plant height was $5 \mathrm{~m}$. The crop was irrigated using subsurface drip irrigation with a daily irrigation depth of $9.5 \mathrm{~mm}$.

The data were collected between October 2005 and June 2006, and divided into two periods, representing the dry (October-December) and the wet seasons (February-May). The eddy covariance (EC) system used to measure the turbulent flux was placed $7 \mathrm{~m}$ above ground level and $2 \mathrm{~m}$ above a row of plants. It is composed of a fast-response open-path infrared gas analyzer (model LI-7500, Licor, Inc., Lincoln, NE, USA) to measure $\mathrm{CO}_{2}$ and $\mathrm{H}_{2} \mathrm{O}$, coupled with a tridimensional sonic anemometer (model CSAT-3, Campbell Scientific, Inc., Logan, UT, USA) used to measure wind speed. The separation between sensors was of $15 \mathrm{~cm}$ and the digital signals from these instruments were sampled at $10 \mathrm{~Hz}$ and averaged at 30-min intervals using a datalogger (CR23X, Campbell Scientific, Inc., Logan, UT, USA), in which the data were stored for later processing.

The net radiation ( $\mathrm{Rn})$ was computed using a fourcomponent (Equation 1) net radiometer (CNR1, Kipp \& Zonnen, Delf, The Netherlands) placed $7 \mathrm{~m}$ above the ground level and $2 \mathrm{~m}$ above a row of plants:

$\mathrm{R}_{\mathrm{n}}=\mathrm{S}_{\text {solar }}-\mathrm{S}_{\text {ref }}+\mathrm{L}_{\text {atm }}-\mathrm{L}_{\text {surface }}$ where $S_{\text {solar }}$ is the incident solar radiation flux, $S_{\text {ref }}$ is the reflected solar radiation flux, $\mathrm{L}_{\mathrm{atm}}$ is the atmospheric longwave radiation flux and $\mathrm{L}_{\text {surface }}$ is the surface longwave radiation flux (Tanaka et al., 2008). 
The soil heat flux $(\mathrm{G})$ was measured with two heat flux plates (HFP01SC-L, Campbell Scientific, Inc., Logan, UT, USA) buried in the ground at a $2 \mathrm{~cm}$ depth, one between the rows and the other on a row between the plants. The values of $\mathrm{G}$ were obtained as the average of the two measurements using the same datalogger. Additionally, microclimatic data of air temperature and relative humidity were sampled every minute using a HMP45C probe (Vaisala, Inc., Helsink, Finland) and averaged at 30-min intervals.

To obtain the reference evapotranspiration $\left(\mathrm{ET}_{0}\right)$ from the combined FAO-Penman-Monteith method (Allen et al., 1998), an automatic weather station (106 Weather Station, Campbell Scientific Inc., Logan, UT, USA) was installed in a pasture in the vicinity of the study plot.

The use of the EC technique is problematic when the specific humidity gradient, and thus the latent heat flux, is very small (Kalthoff el al., 2006). The EC technique acquires the turbulent fluxes by measuring the fluctuations around a long-term mean, i.e. the sensible heat flux is calculated according to the following equation: $\mathrm{H}=\left(\bar{\rho}_{\mathrm{d}} \mathrm{C}_{\mathrm{pd}}+\bar{\rho}_{\mathrm{v}} \mathrm{C}_{\mathrm{pv}}\right) \overline{\mathrm{W}^{\prime \prime T}} \quad$ (2), and the latent heat flux is calculated using the equation: $\mathrm{LE}=\bar{\rho}_{\mathrm{v}} 1 \overline{\mathrm{w}^{\prime} \mathrm{q}_{\mathrm{v}}^{\prime}}$

where $\mathrm{C}_{\mathrm{pd}}$ and $\mathrm{C}_{\mathrm{pv}}$ are the specific heat capacities of dry air and water vapor respectively. The overbar in Equations (2) and (3) denotes the 30-min time average. $\rho_{\mathrm{d}}$ and $\rho_{\mathrm{v}}$ are the densities of dry air and water vapor respectively, $\mathrm{w}^{\prime}$ is the vertical wind speed fluctuation, $T^{\prime}$ is the air temperature fluctuation, $q^{\prime}$ is the specific humidity fluctuation, and 1 is the latent water heat $\left(2.508 \times 10^{6} \mathrm{~J} \mathrm{~kg}^{-1}\right)$. Only the Webb correction (Webb et al., 1980) included in Equations (2) and (3) was applied to this data analysis, and the correction to transverse wind was used when obtaining wind speed (Tanaka et al., 2003).

As the energy balance components were measured independently, it was necessary to check the energy balance closure, because recent flux studies with EC have shown that this balance is usually not closed (Verma et al., 1986; Twine et al., 2000; Ohta et al., 2001; Tanaka et al., 2008). Heat fluxes (H + LE) and available energy ( $\mathrm{Rn}-\mathrm{G})$ were compared daily for the two seasons. In theory, if there are no errors above the same fetch, equation (4) can be used. Wilson et al. (2002) have shown that the energy balance closure requires that the sum of the estimated latent
(LE) and sensible $(\mathrm{H})$ heat fluxes are equivalent to the available energy $\left(R_{n}-G\right)$ :

$\mathrm{CR}=(\mathrm{H}+\mathrm{LE}) /\left(\mathrm{R}_{\mathrm{n}}-\mathrm{G}\right)$

where $R_{n}$ is the net radiation and $G$ is the soil heat flux.

\section{Results and Discussion}

Figure 1 shows the maximum, average and minimum daily values of the significant microclimatic variables during the two growing seasons studied. The wind speed $(\mathrm{u})$ reached daily maximum values higher than $4 \mathrm{~m} \mathrm{~s}^{-1}$ for most of the days during the dry season (Figure $1 \mathrm{~A}$ ) with averages between 2 and $3.5 \mathrm{~m} \mathrm{~s}^{-1}$, showing stronger wind advection during this season. During the beginning of the wet season (Figure $1 \mathrm{~B}$ ) wind behavior was similar to the dry season, but then decreasing continuously until the $134^{\text {th }}$ day of year (DOY). During the wet season, the minimum values stayed below $0.5 \mathrm{~m} \mathrm{~s}^{-1}$ and the maximum values varied between 2 and $4 \mathrm{~m} \mathrm{~s}^{-1}$, with mean values between 1 and $2.5 \mathrm{~m} \mathrm{~s}^{-1}$. These data show that the daily $u$ values in the wet season are lower than in the dry season.

The vapor pressure deficit (VPD), which is the difference between the saturation $\left(\mathrm{e}_{\mathrm{s}}\right)$ and actual vapor pressure $\left(\mathrm{e}_{\mathrm{a}}\right)$ for a given time period, is presented in Figure $1 \mathrm{C}$ and D for the dry and wet seasons, respectively. It varied between $4.3 \mathrm{kPa}$ and $3.6 \mathrm{kPa}$ in the dry season and between $3.2 \mathrm{kPa}$ and $4.2 \mathrm{kPa}$ in the wet season. Both Figures show the continuous high atmospheric water demand and its decrease during the wet season (Figure $1 \mathrm{D})$.

Air temperature reached the maximum values above $34^{\circ} \mathrm{C}$, mean values between 26 and $30^{\circ} \mathrm{C}$, and minimum values below $24^{\circ} \mathrm{C}$ during the dry season (Figure $1 \mathrm{E}$ ). In the wet season it decreased gradually (Figure $1 \mathrm{~F}$ ). The maximum varied between 36 and $30^{\circ} \mathrm{C}$, with means between 28 and $25^{\circ} \mathrm{C}$ and a minimum below $24^{\circ} \mathrm{C}$. It is evident that air temperature has a behavior similar to that of deserts during the dry season, higher during the day and lower at night.

Dry and wet season (Table 1) data were analyzed using linear regression to identify which of the climate parameters have more influence on evapotranspiration in the region under study. The 
results show that all the correlations are significant for the specified significance level.

It appears that $u$ is the most influential component of the dry season on $\mathrm{ET}_{0}$, while $\mathrm{u}, \mathrm{VPD}$ and air temperature showed strong correlation in the wet season (Table 1). These results indicate that during the dry season, when atmospheric water deficit is higher, $\mathrm{u}$ is the main component in the evaporative process, because evapotranspiration is largely dependent on air turbulence, which is responsible for transferring large quantities of water vapor from the evaporating surface (Allen et al., 1998); it is followed by vapor pressure deficit, which represents air dryness (Table 1). In the wet season a stronger influence of $u$ on evapotranspiration (Table 1) is again evidenced, followed by VPD. Theoretically, with the possibility of unlimited water use and the same available energy, evapotranspiration should vary with $u$ and air VPD, according to Dalton's law (Brutsaert, 1982). Water use in the study area was not limited, because it was irrigated daily. In agreement with Brunel et al. (2006), for similar conditions of VPD and available energy, evapotranspiration increases with the increase of $u$ (Table 1).
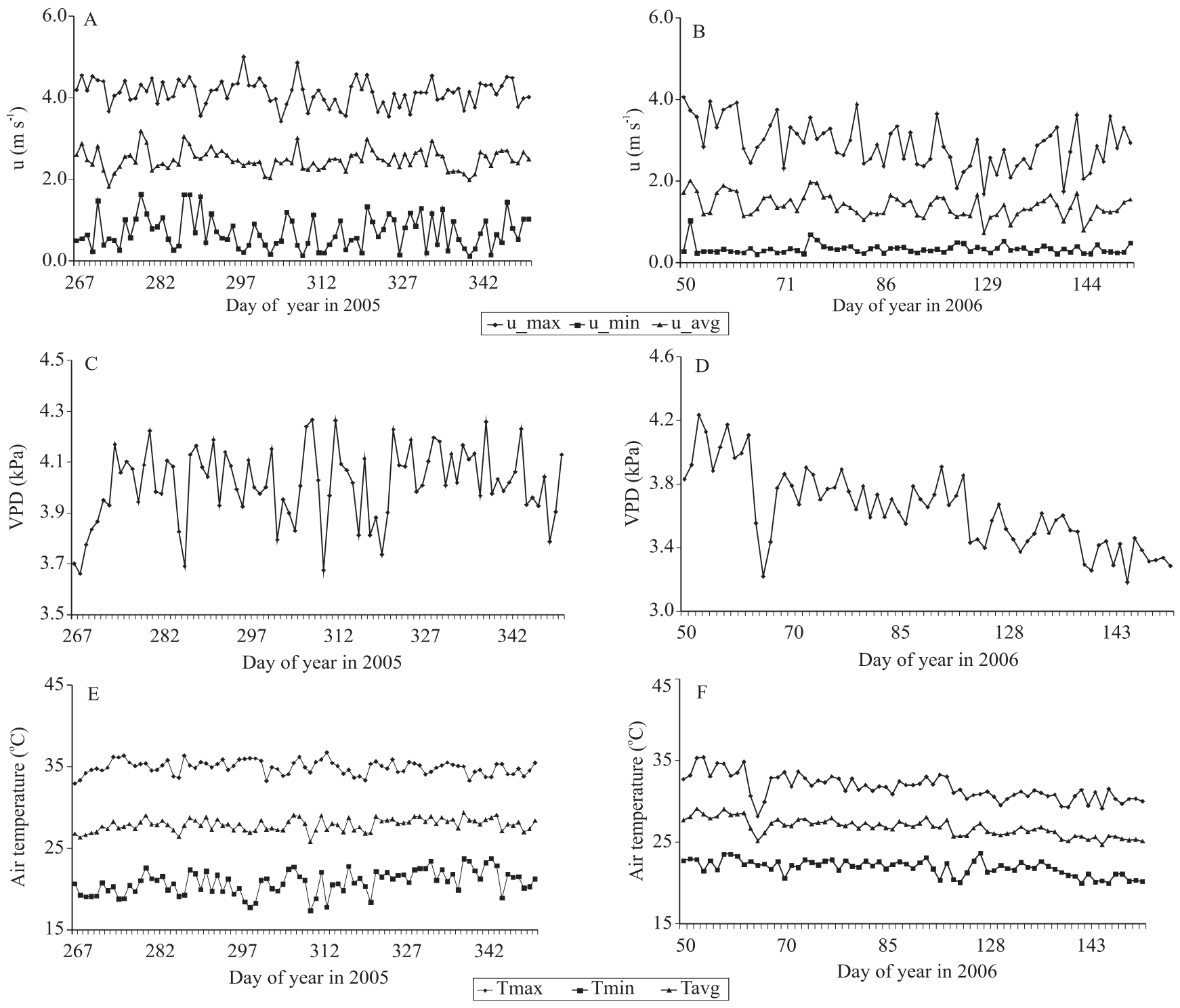

Figure 1. Time series of wind speed (u), vapor pressure deficit (VPD) and air temperature in the experimental banana field during the dry (2005, A, C and E) and wet (2006, B, D and F) growing season. 
Thus, $u$ and VPD are the most influential variables on the evaporative process in both seasons. Based on this, the ETa was compared with those variables (Figure 2). The correlation coefficients (r) between $\mathrm{u}$ and ETa were of 0.35 and 0.09 , and between VPD and ETa of 0.23 and 0.20 for the dry and wet growing seasons respectively. The results show that all the correlations are significant. They also show that there are no higher correlations between the climatic variables ( $\mathrm{u}$ and VPD) and the ETa measured using the EC system, indicating that the EC system used in this study did not present better agreement with the reference ET system.
Two days in each season were selected to represent the typical diurnal cycles of surface energy fluxes (Figure 3). The net radiation, which was greater than $700 \mathrm{~W} \mathrm{~m}^{-2}$, showed similar behavior. A large portion of $R_{n}$ was converted into latent heat flux, which values of up to $400 \mathrm{~W} \mathrm{~m}^{-2}$ at midday, regardless of the season. However, $\mathrm{H}$ has values closer than those shown by LE in the dry season.

The average energy flux balances were higher during the dry season (Table 2). The differences in energy flux partitioning were distinctive for the two growing seasons. $\mathrm{H}$ and LE were similar during the dry season, but, LE was usually higher than $\mathrm{H}$ under

Table 1. Linear correlations between air temperature, solar radiation, wind speed and vapor pressure deficit with reference evapotranspiration during the dry (2005) and wet (2006) growing seasons in an irrigated banana orchard.

\begin{tabular}{|c|c|c|c|c|c|c|c|c|}
\hline \multirow[t]{2}{*}{$\mathrm{ET}_{0}$ Variables } & \multicolumn{4}{|c|}{2005 (dry) } & \multicolumn{4}{|c|}{2006 (wet) } \\
\hline & Linear equation & $\mathrm{r}$ & $\mathrm{t}_{\text {calculated }}$ & $\mathrm{t}_{(\mathrm{p}=0.01)}(\mathrm{n}=99)$ & Linear equation & $\mathrm{r}$ & $\mathrm{t}_{\text {calculated }}$ & $\mathrm{t}_{(\mathrm{p}=0.01)}(\mathrm{n}=69)$ \\
\hline Air temperature & $y=0.21 x+2.4$ & $0.30^{* *}$ & 3.1 & & $y=0.71 x-13.8$ & $0.80^{* *}$ & 11.0 & \\
\hline Solar radiation & $y=0.01 x+6.2$ & $0.47^{* *}$ & 5.2 & 2.39 & $y=0.01 x+2.1$ & $0.57^{* *}$ & 5.6 & 2.39 \\
\hline Wind speed & $y=1.86 x+3.3$ & $0.94^{* *}$ & 26.8 & & $y=2.86 x+1.3$ & $0.96^{* *}$ & 28.9 & \\
\hline VPD & $y=1.26 x+3.3$ & $0.36^{* *}$ & 3.8 & & $y=3.00 x-6.0$ & $0.81^{* *}$ & 11.4 & \\
\hline
\end{tabular}

**Significant by Student's $t$ test, at $1 \%$ of probability.
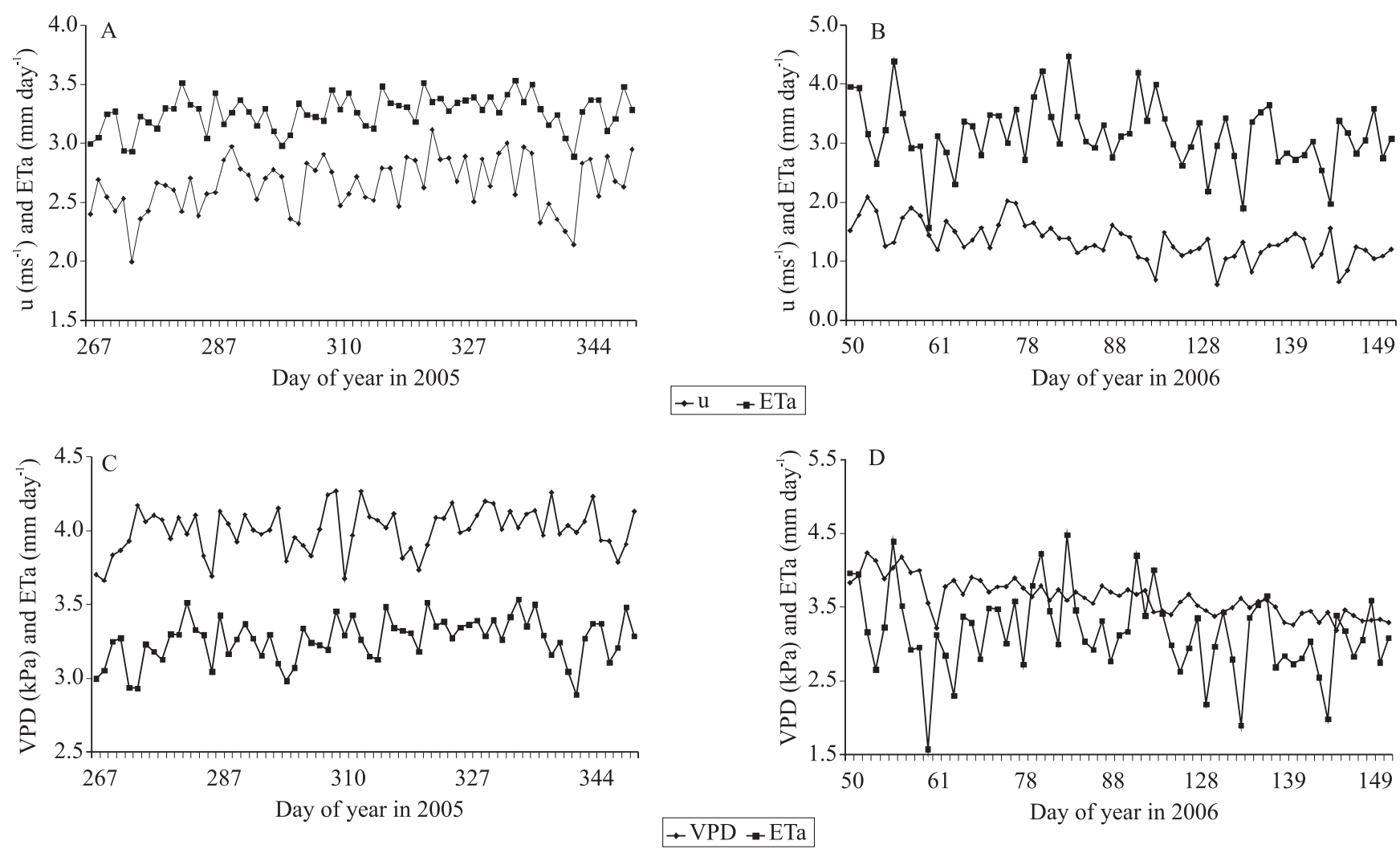

Figure 2. Comparison between wind speed (u), vapor pressure deficit (VPD) and actual evapotranspiration (ETa) for the irrigated banana orchard in the dry (2005, A and C) and wet (2006, B and D) growing season. 
wet conditions. $G$ varied during the day, reaching peaks of $100 \mathrm{~W} \mathrm{~m}^{-2}$ in the dry season, and was lower during the wet season, due to more cloud cover and higher soil moisture. Energy flux seasonal behavior is shown in Figure 4.

During the dry season, the ETa varied between 2.9 and $3.5 \mathrm{~mm}^{-1 a y}{ }^{-1}$, with an average of $3.3 \mathrm{~mm}^{-1 a y}{ }^{-1}$. In the wet season, variation was between 1.6 and $4.5 \mathrm{~mm} \mathrm{day}^{-1}$, averaging $3.1 \mathrm{~mm} \mathrm{day}^{-1}$ (Figure $5 \mathrm{~A}$ ), showing the high variability and sensitivity of the ETa measured by the eddy covariance technique during the rainy season. These results agree with those of Van Vosselen et al. (2005) and Montenegro et al. (2008). Using the water balance method, Van Vosselen et al. (2005) found a mean ETa of $3.2 \mathrm{~mm} \mathrm{day}^{-1}$, and Montenegro et al. (2008) found ETa values of between $2.6 \mathrm{~mm} \mathrm{day}^{-1}$ and $4.3 \mathrm{~mm} \mathrm{day}^{-1}$. The monthly crop coefficients $(\mathrm{Kc})$ for
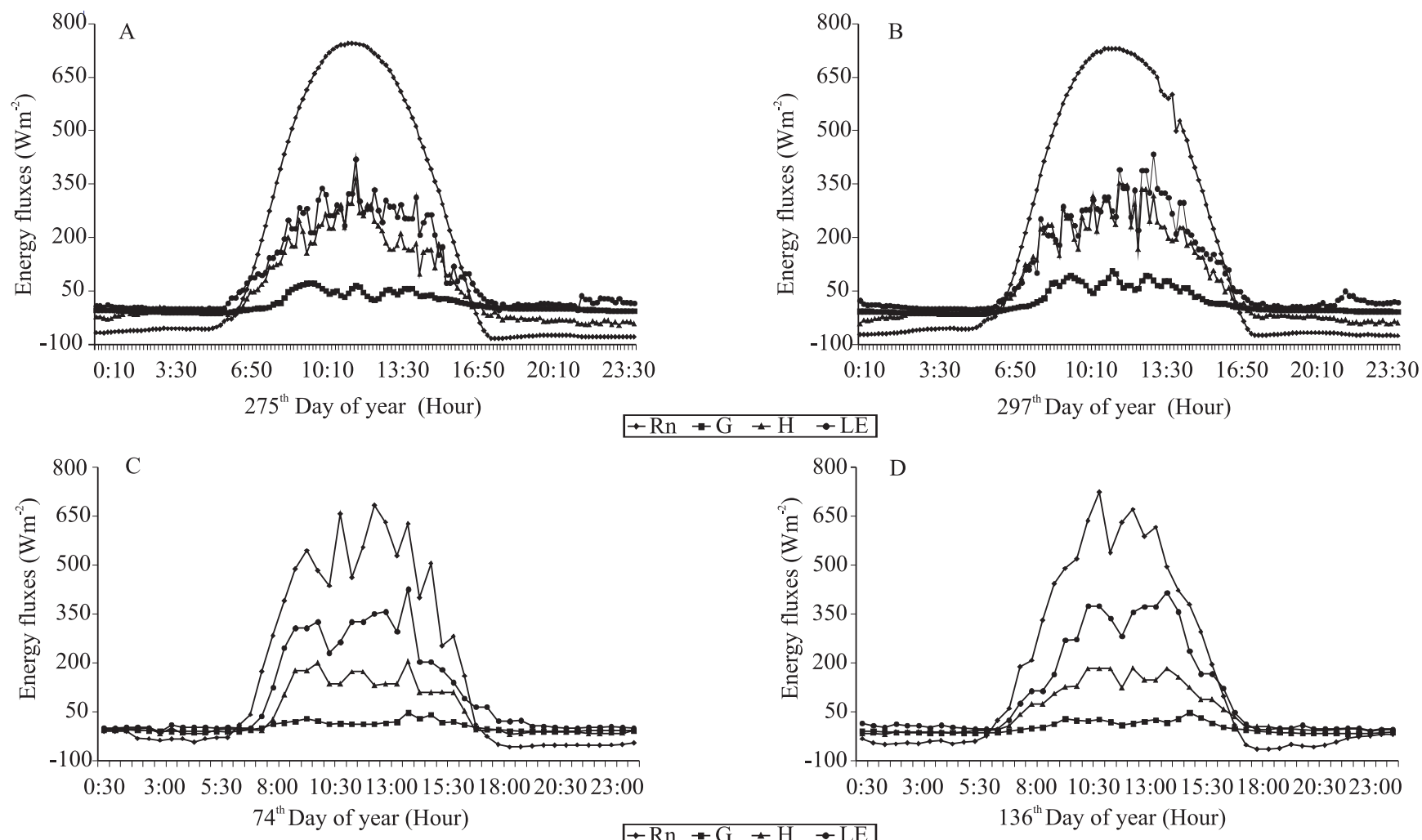

$\rightarrow \mathrm{Rn} \rightarrow \mathrm{G} \leftarrow \mathrm{H} \rightarrow \mathrm{LE}$

$297^{\text {th }}$ Day of year (Hour)

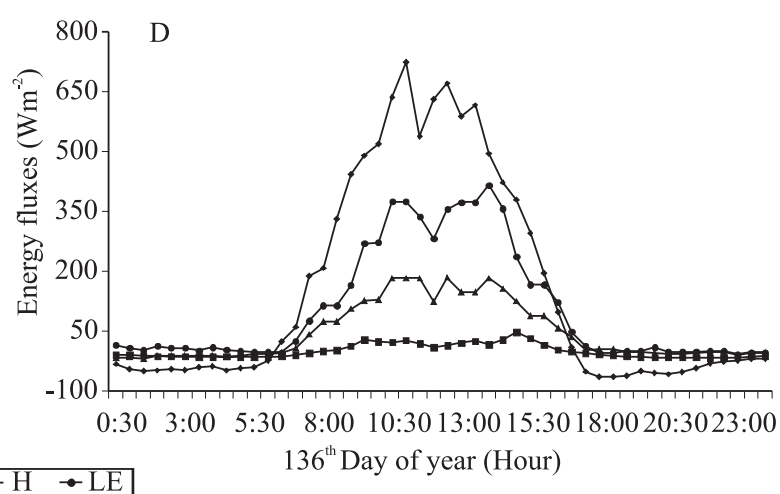

Figure 3. Energy balance components, net radiation $(\mathrm{Rn})$, soil heat flux $(\mathrm{G})$, sensible heat flux $(\mathrm{H})$ and latent heat flux (LE), for four typical days, $275^{\text {th }}$ and $297^{\text {th }}$ (clear sky) day of year (DOY), in 2005, and $74^{\text {th }}$ and $136^{\text {th }}$ (cloudy) DOY in 2006, over an irrigated banana orchard.

Table 2. Statistical parameters of the average daytime energy fluxes over the irrigated banana orchard in the dry (2005) and wet (2006) growing seasons.

\begin{tabular}{|c|c|c|c|c|}
\hline Energy fluxes & Average & Maximum & Minimum & Standard deviation \\
\hline & \multicolumn{4}{|c|}{ Dry growing season (2005) } \\
\hline $\mathrm{R}_{\mathrm{n}}\left(\mathrm{Wm}^{-2}\right)$ & 447.2 & 523.5 & 317.5 & 39.1 \\
\hline $\mathrm{G}\left(\mathrm{Wm}^{-2}\right)$ & 31.6 & 52.4 & 14.6 & 9.0 \\
\hline $\mathrm{H}\left(\mathrm{Wm}^{-2}\right)$ & 160.2 & 229.1 & 83.6 & 32.2 \\
\hline \multirow[t]{2}{*}{$\operatorname{LE}\left(\mathrm{Wm}^{-2}\right)$} & 216.8 & 244.3 & 169.7 & 14.4 \\
\hline & \multicolumn{4}{|c|}{ Wet growing season (2006) } \\
\hline $\mathrm{R}_{\mathrm{n}}\left(\mathrm{Wm}^{-2}\right)$ & 370.6 & 493.7 & 221.7 & 67.6 \\
\hline $\mathrm{G}\left(\mathrm{Wm}^{-2}\right)$ & 17.8 & 29.1 & 4.0 & 6.5 \\
\hline $\mathrm{H}\left(\mathrm{Wm}^{-2}\right)$ & 106.6 & 173.1 & 36.4 & 33.8 \\
\hline $\mathrm{LE}\left(\mathrm{Wm}^{-2}\right)$ & 197.3 & 259.7 & 123.5 & 31.6 \\
\hline
\end{tabular}


the irrigated banana orchard in the 2005 dry season were of $0.52,0.52,0.54$ and 0.57 for September, October, November and December respectively, and for the 2006 wet growing season, 0.58, 0.67, $0.76,0.75$ and 0.76 for January, February, March, April and May respectively. There is a small variation in the Kc values, which ranged from 0.52 in the dry season to 0.76 in the wet season. The Kc results are lower than those found by Montenegro et al. (2008), who reported Kc values of between 0.60 and 1.05. Energy balance closure is an important criterion for evaluating the quality of measured heat flux data from EC systems (Yao et al., 2008). Various studies have shown that this balance typically does not close (Verma et al., 1986;
Tanaka et al., 2008), and the possible reasons can be: sampling error, instrument error, losses of high and low frequencies, ignoring some energy items and advection (Yao et al., 2008). During the dry season, the energy balance closure varied between 0.79 and 1.05 with a mean of 0.93 , which can be considered a good result (Figure 6 A). In the wet season, the energy balance closure varied between 0.63 and 1.06 with a mean of 0.86 (Figure $6 \mathrm{~B}$ ). These results agree with Stannard et al. (1994), who reported typical values of energy balance closure for agricultural lands of between 0.80 and 0.90 , and according to Twine et al. (2000) this error is tolerable for irrigation scheduling.
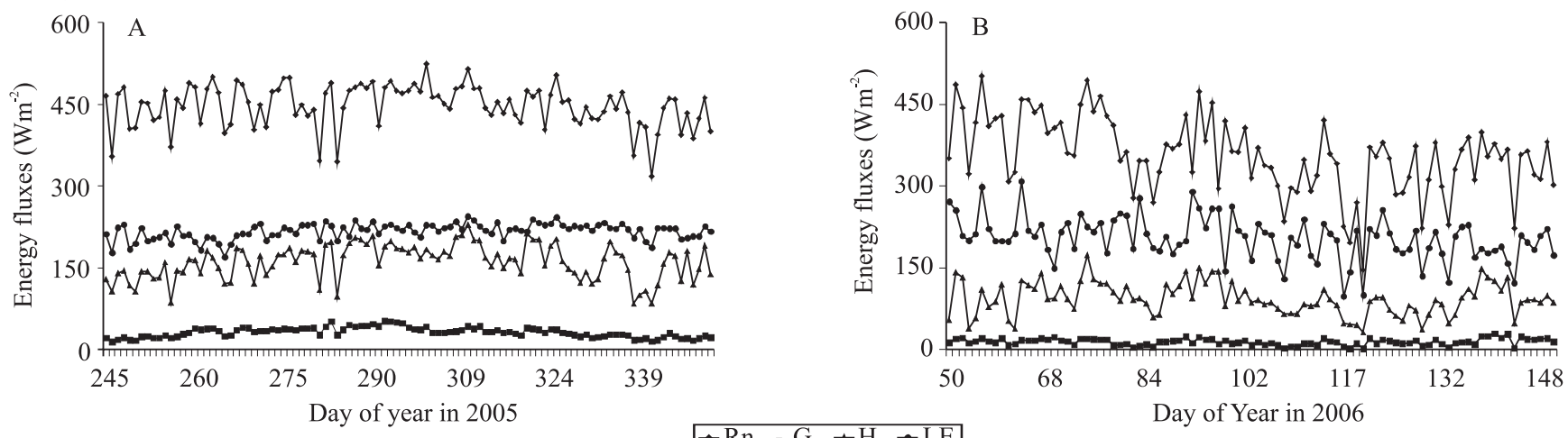

Figure 4. Mean daily values of the energy fluxes, net radiation $(\mathrm{Rn})$, soil heat flux $(\mathrm{G})$, sensible heat flux (H) and latent heat flux (LE), in the irrigated banana orchard by using the eddy covariance system during the dry (A) and wet (B) growing seasons.
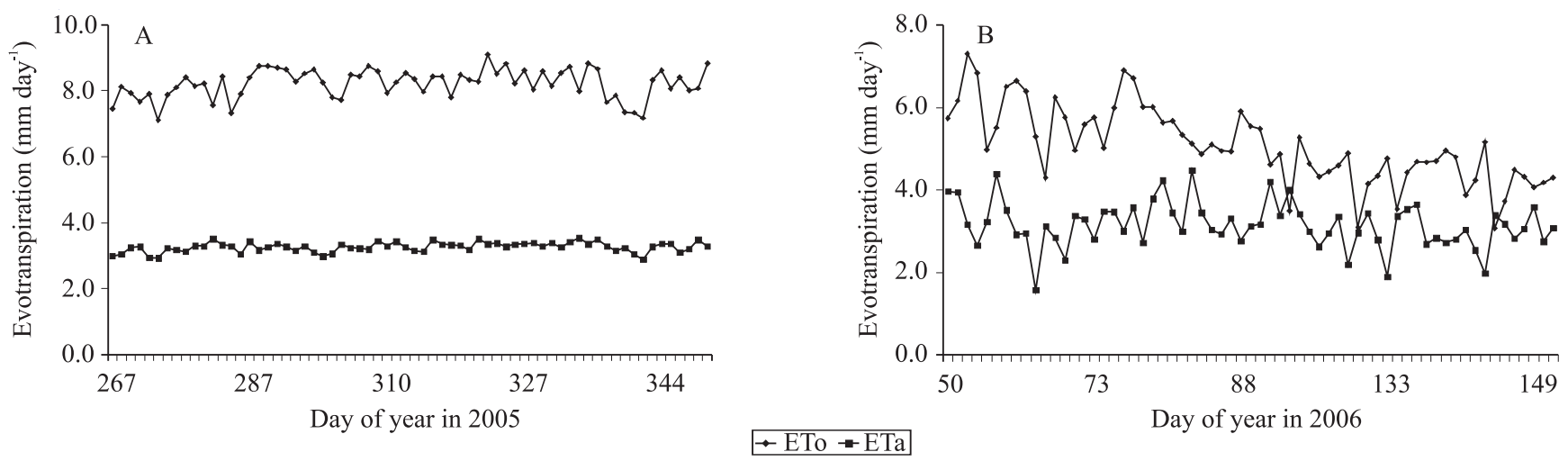

Figure 5. Temporal distribution of the reference evapotranspiration $\left(\mathrm{ET}_{\mathrm{o}}\right)$ and actual evapotranspiration (ETa) during the dry (A) and wet (B) growing seasons in an irrigated banana orchard. 

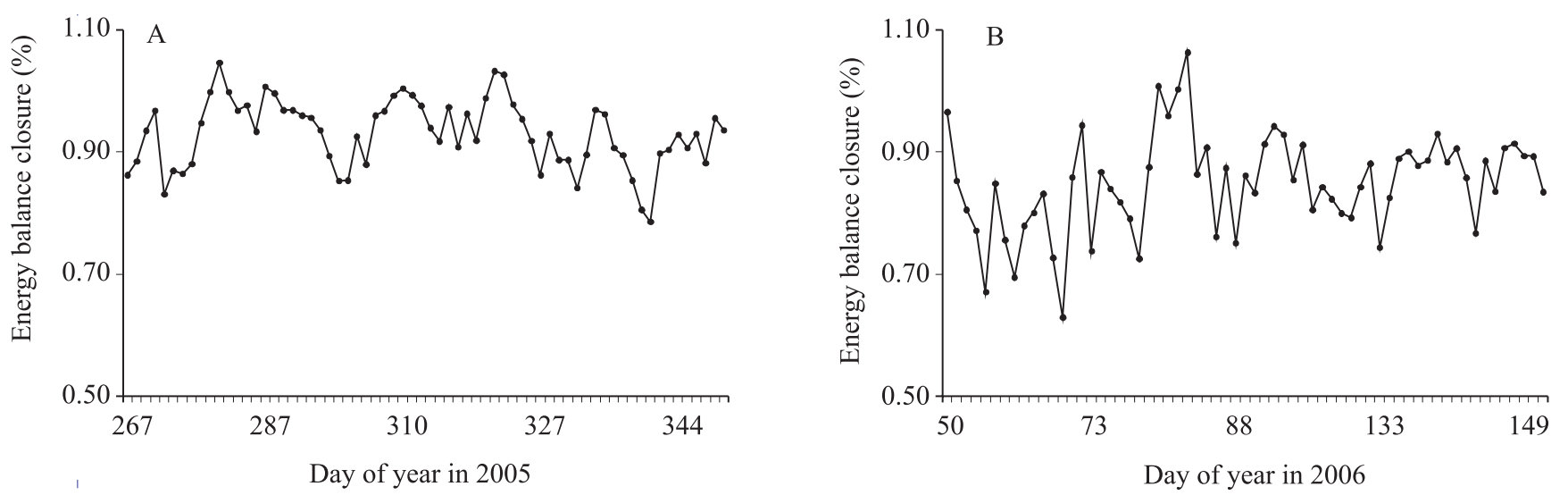

Figure 6. Energy balance closure for dry (A) and wet (B) growing season in an irrigated banana orchard.

\section{Conclusions}

1. The largest part of the net radiation is transformed into latent heat flux during the dry conditions in an irrigated banana orchard, regardless of the growing season.

2. During daytime in an irrigated banana orchard, the sensible and latent heat fluxes are similar in the dry season, while the latent heat flux is usually higher than the sensible heat flux during the wet season.

3. Eddy covariance has shown acceptable reliability in measuring heat flux, with actual evapotranspiration data comparing well with those obtained by using the water balance method for an irrigated banana orchard.

4. The energy balance closure presents good results for the irrigated banana orchard, with mean values of 0.93 and 0.86 for the dry and wet growing seasons respectively.

\section{Acknowledgements}

To Conselho Nacional de Desenvolvimento Científico e Tecnológico, for scholarships and financial support; to the Frutacor farm, which furnished the planted areas used in this experiment; and to the Remote Sensing Services Laboratory of the Biological and Irrigation Engineering Department at Utah State University, for additional support.

\section{References}

ALlEN, R.G.; PEREIRA, L.S.; RAES, D.; SMITH, M. Crop evapotranspiration: guidelines for computing crop requirements. Rome: FAO, 1998. 331p. (FAO. Irrigation and Drainage Paper, 56).
BALDOCCHI, D.D. Assessing the eddy covariance technique for evaluating carbon dioxide exchange rates of ecosystems: past, present and future. Global Change Biology, v.9, p.479-492, 2003.

BASSOI, L.H.; TEIXEIRA, A.H. de C.; LIMA FILHO, J.M.P.; SILVA, J.A.M. e; SILVA, E.E.G. da; RAMOS, C.M.C.; SEDIYAMA, G.C. Guidelines for irrigation scheduling of banana crop in São Francisco Valley, Brazil. II - Water consumption, crop coefficient, and physiological behavior. Revista Brasileira de Fruticultura, v.26, p.464-467, 2004.

BRUNEL, J.-P.; IHAB, J.; DROUBI, A.M.; SAMAAN, S. Energy budget and actual evapotranspiration of an arid oasis ecosystem: Palmyra (Syria). Agricultural Water Management, v.84, p.213-220, 2006.

BRUTSAERT, W. Evaporation into the atmosphere: theory, history and applications. Dordrecht: Kluwer Academic, 1982. 291p.

GIOLIA, B.; MIGLIETTA, F.; DE MARTINO, B.; HUTJES, R.W.A.; DOLMAN, H.A.J.; LINDROTH, A.; SCHUMACHER, M.; SANZ, M.J.; MANCA, G.; PERESSOTTI, A.; DUMAS, E.J. Comparison between tower and aircraft-based eddy covariance fluxes in five European regions. Agricultural and Forest Meteorology, v.127, p.1-16, 2004.

KALTHOFF, N.; FIEBIG-WITTMAACK, M.; MEISSNER, C.; KOHLER, M.; URIARTE, M.; BISCHOFF-GAUSS, I.; GONZALES, E. The energy balance, evapo-transpiration and nocturnal dew deposition of an arid valley in the Andes. Journal of Arid Environments, v.65, p.420-443, 2006.

LU, P.; WOO, K.C.; LIU, Z.T. Estimation of whole-plant transpiration of bananas using sap flow measurements. Journal of Experimental Botany, v.53, p.1771-1779, 2002.

MONTENEGRO, A.A.T.; GOMES, A.R.M.; MIRANDA, F.R. de; CRISÓSTOMO, L.A. Evapotranspiração e coeficiente de cultivo da bananeira para a região litorânea do Ceará. Revista Ciência Agronômica, v.39, p.203-208, 2008.

OHTA, T.; HIYAMA, T.; TANAKA, H.; KUWADA, T.; MAXIMOV, T.C.; OHATA, T.; FUKUSHIMA, Y. Seasonal variation in the energy and water exchanges above and below a 
larch forest in eastern Siberia. Hydrological Processes, v.15, p.1459-1476, 2001.

PAÇO, T.A.; FERREIRA, M.I.; CONCEIÇÃO, N. Peach orchard evapotranspiration in a sandy soil: comparison between eddy covariance measurements and estimates by the FAO 56 approach. Agricultural Water Management, v.85, p.305-313, 2006.

ROBINSON, J.C. System of cultivation and management. In: GOWEN, S. (Ed.). Bananas and plantains. London: Chapman \& Hall, 1995. p.15-65.

SILVA, A.J.P. da; COELHO, E.F.; MIRANDA, J.H. de; WORKMAN, S.R. Estimating water application efficiency for drip irrigation emitter patterns on banana. Pesquisa Agropecuária Brasileira, v.44, p.730-737, 2009.

SIMMONS, L.J.; WANG, J.; SAMMIS, T.W.; MILLER, D.R. An evaluation of two inexpensive energy-balance techniques for measuring water use in flood-irrigated pecans (Carya illinoinensis). Agricultural Water Management, v.88, p.181-191, 2007.

SISTEMA brasileiro de classificação de solos. Brasília: Embrapa Produção de Informação; Rio de Janeiro: Embrapa Solos, 1999. 412p.

STANNARD, D.I.; BLANFORD, J.H.; KUSTAS, W.P.; NICHOLS, W.D.; AMER, S.A.; SHUMUGGE, T.J.; WELTZ, M.A. Interpretation of surface flux measurements in heterogeneous terrain during the Monsoon 90 Experiment. Water Resources Research, v.30, p.1227-1239, 1994.

TANAKA, H.; HIYAMA, T.; KOBAYASHI, N.; YABUKI, H.; ISHII, Y.; DESYATKIN, R.V.; MAXIMOV, T.C.; OHTA, T. Energy balance and its closure over a young larch forest in eastern Siberia. Agricultural and Forest Meteorology, v.148, p.1954-1967, 2008 .

TANAKA, K.; TAMAGAWA, I.; ISHIKAWA, H.; MA, Y.; HU, Z. Surface energy budget and closure of the eastern Tibetan Plateau during the GAME-Tibet IOP 1998. Journal of Hydrology, v.283, p.169-183, 2003.
TEIXEIRA, A.H. de C.; BASTIAANSSEN, W.G.M.; MOURA, M.S.B.; SOARES, J.M.; AHMAD, M.D.; BOS, M.G. Energy and water balance measurements for water productivity analysis in irrigated mango trees, Northeast Brazil. Agricultural and Forest Meteorology, v.148, p.1524-1537, 2008.

TWINE, T.E.; KUSTAS, W.P.; NORMAN, J.M.; COOK, D.R.; HOUSER, P.R.; MEYERS, T.P.; PRUEGER, J.H.; STARKS, P.J.; WESELY, M.L. Correcting eddy-covariance flux underestimates over a grassland. Agricultural and Forest Meteorology, v.103, p.279-300, 2000.

VAN VOSSELENA, A.; VERPLANCKE, H.; VAN RANST, E. Assessing water consumption of banana: traditional versus modelling approach. Agricultural Water Management, v.74, p.201-218, 2005.

VERMA, S.B.; BALDOCCHI, D.D.; ANDERSON, D.E.; MATT, D.R.; CLEMENT, R.J. Eddy fluxes of $\mathrm{CO}_{2}$, water vapor, and sensible heat over a deciduous forest. Boundary-Layer Meteorology, v.36, p.71-91, 1986.

WEBB, E.K.; PEARMAN, G.I.; LEUNING, R. Correction of flux measurements for density effects due to heat and water vapour transfer. Quarterly Journal of the Royal Meteorological Society, v.106, p.85-100, 1980.

WILSON, K.; GOLDSTEIN, A.; FALGE, E.; AUBINET, M.; BALDOCCHI, D.D.; BERBIGIER, P.; BERNHOFER, C.; CEULEMANS, R.; DOLMAN, H.; FIELD, C.; GRELlE, A.; IBROM, A.; LAW, B.E.; KOWALSKI, A.; MEYERS, T.; MONCRIEFF, J.; MONSON, R.; OECHEL, W.; TENHUNEN, J.; VALENTINI, R.; VERMA, S. Energy balance closure at FLUXNET sites. Agricultural and Forest Meteorology, v.113, p.223-243, 2002.

YAO, J.; ZHAO, L.; DING, Y.; GU, L.G.; JIAO, K.; QIAO, Y.P.; WANG, Y.X. The surface energy budget and evapotranspiration in the Tanggula region on the Tibetan Plateau. Cold Regions Science and Technology, v.52, p.326-340, 2008.

Received on April 4, 2009 and accepted on October 29, 2009 